\title{
Determinants of Bank Stability: A Financial Statement Analysis of Turkish Banks'
}

Gamze Öztürk DANIŞMAN (https://orcid.org/0000-0003-3684-6692), Department of Management, Boğaziçi

University, Turkey; e-mail: danisman.gamze@gmail.com

\section{Banka İstikrarının Belirleyicileri: Türkiye'deki Bankaların Mali Tabloları Üzerinde Bir İnceleme ${ }^{2}$}

\begin{abstract}
This paper attempts a financial statement analysis of Turkish banks and explores the determinants of bank stability, as proxied by non-performing loans ratio, using annual data on 27 Turkish banks for the years 2007-2015. We employ dynamic panel data estimation techniques by using the system GMM estimation techniques. Our results indicate that the significant determinants of NPLs that are able to explain the credit risk of Turkish banks include return on assets (ROA), loans to asset ratio, inefficiency index, non-interest income share and loan loss provisions share. We contribute to the literature by properly accounting for endogeneity with adequate specification and validation tests.
\end{abstract}

Keywords $\quad$ : Bank Stability, Credit Risk, Non-performing Loans, Determinants, System-GMM.

JEL Classification Codes : $\quad$ C23, G21.

$\ddot{\mathbf{O} z}$

$\mathrm{Bu}$ çalışmada, Türk bankalarının mali tablo analizi ve takipteki kredilerin belirleyicileri incelenmektedir. 2007-2015 yılları için 27 adet Türk bankasının yıllık verileri kullanılmıștır. Sistem GMM yöntemiyle dinamik panel veri analizi metodolojisi kullanılmıştır. Bulgulara göre, bankalara özgü belirleyiciler aktif kârlılık, krediler-varlık toplamı oranı, verimsizlik endeksi, faiz dıșı gelir oranı ve kredi zararı karşılıkları oranı olarak belirlenmiştir. Bu çalışma ile endojenite spesifikasyon ve doğrulama testleri uygun bir şekilde kontrol edilerek literatüre katkıda bulunmak amaçlanmaktadır.

Anahtar Sözcükler : Banka İstikrarı, Kredi Riski, Takipteki Krediler, Belirleyiciler, Sistem-GMM.

1 This study created from the Ph.D. dissertation of Gamze Öztürk Danışman conducted in the Management Department of Bogazici University, Istanbul, Turkey, in 2018. The author would like to thank Dr. Pelin Demirel for providing the dataset for this study.

2 Bu çalışma, yazarın Boğaziçi Üniversitesi Işsletme Anabilim Dalında, 2018 yllında savunduğu doktora tezinden üretilmiştir. Yazar, bu çalışma için veri setini temin eden Dr. Pelin Demirel'e ayrica teşekkür etmektedir. 


\section{Introduction}

Before the recent 2007-2009 financial crisis, the non-performing loan (NPL) ratios of banks in various countries remained stable. However, since then the asset quality of banks started to deteriorate and the NPL ratios increased which brought concerns over the credit quality of banks. It is well known that the asset quality of banks is highly correlated with economic cycles (Beck et al., 2013). NPLs of banks bring liquidity and insolvency problems to the financial system which may give rise to a banking crisis (Castro, 2013) and therefore alarms the regulatory authorities to undertake prompt actions to prevent it. The recent financial crisis of 2007-2009 showed that credit risk of banks results in negative externalities for the whole financial system and the overall economy. Therefore, exploring the indicators of the credit risk of banks is crucial for regulatory authorities to preserve stability in the financial system (Louzis et al., 2010).

The banking sector is the pioneer of the Turkish financial system because the total banking sector assets constitute $87 \%$ percent of the financial system in Turkey (CBRT, 2013). In the late 1990s, Turkish economy was very fragile with high inflation rates and large budget deficits. Banks were not able to expand credit to the economy which further led to the 2001 economic crisis. Many Turkish banks were either insolvent or were subject to consolidation during the crisis of 2001. Banks faced reduced interest margins which led them to increase their loan share in total assets and thereby decrease the share of government securities (Macit, 2012). After the 2007-2009 global financial crisis, the Central Bank of the Republic of Turkey (CBRT) aimed to induce more stability in banks by keeping the NPL ratios at low levels because NPLs are accepted as of the main indicators for financial stability in banks (Us, 2016). Turkish banks are quite successful in managing their NPLs and the asset quality of banks is quite strong. For instance, from 2012 to 2017, Turkish banks' average NPLs ratio was flat around 3\% (CBRT, 2017) which is close to the average of peer developing countries. The afore-mentioned discussions motivate to explore the following research questions throughout the paper: What are the determinants of bank stability for Turkish banks? Are bank-specific of macroeconomic indicators more relevant in explaining NPLs? Our aim in this paper is to conduct a financial statement analysis of Turkish banks by exploring the determinants of NPLs which would help understand the dynamics behind the problematic loans and help for better policies and actions.

The literature provides two sets of factors explaining bank credit risk. The first investigates the macroeconomic determinants which gained interest since the emergence of the financial crisis of 2007-2009 and these studies are generally cross-country (Espinoza \& Prasad, 2010; Nkusu, 2011; Skarica, 2014). The second set of studies, on the other hand, emphasizes the bank-specific factors and focus on single countries (Salas \& Saurina, 2002; Louzis et al., 2010; Ghosh, 2015). The empirical literature finds support for both of these factors. Our hypothesis is that the bank-specific factors play a key role in determining the credit risk of Turkish banks. As one of the key ingredients of the macroprudential policy includes credit quality of the financial sector, a comprehensive analysis of the indicators of credit risk will help identify the vulnerabilities of Turkish banks. 
The empirical analysis uses annual data on 27 private and listed Turkish banks for the years 2007-2015. We employ dynamic panel data estimation techniques by using the system GMM estimation techniques developed by Arellano and Bover (1995) and Blundell and Bond (1998). Our results are in line with our hypothesis which indicates that the significant determinants of NPLs are mainly bank-specific factors which include return on assets (ROA), Loans to asset ratio, inefficiency, non-interest income share and loan loss provisions share.

While there are many studies in the literature exploring the indicators of the credit risk of banks, few of them use adequate methodologies to account for endogeneity. We contribute to the extant literature with our selected methodology, the system GMM estimation with adequate specification and validation tests. Moreover, we contribute to the literature by exploring a wide range of bank-specific variables as possible determinants of credit risk.

The rest of the paper is structured as follows: Section 2 provides a brief review of the literature and Section 3 presents Data and Methodology. Section 4 continues with results, and finally, Section 5 concludes.

\section{Literature Review}

The literature reveals two sets of factors explaining bank credit risk. The first group investigates the macroeconomic determinants that affect the borrower's likelihood of repaying their loans which gained interest since the emergence of the financial crisis of 20072009 (Skarica, 2014) and these studies are generally cross-country studies. The second set of studies, on the other hand, emphasizes the bank-specific factors affecting the NPLs of banks and variability of this ratio across different banks which commonly focus on single countries. Empirical literature explained below, finds support for both set of factors. The empirical studies on the determinants of NPLs have theoretical foundations on the models that investigate the role of business cycles on financial intermediation, namely the financial accelerator theory (Bernanke \& Gertler, 1989; Kiyotaki \& Moore, 1997).

Cross-country empirical studies became more evident after the recent financial crisis of 2007-2009. One of them includes Espinoza and Prasad (2010) which explores Gulf Cooperation Council (GCC) countries and uses a sample of 80 banks for the period 1995 to 2008. Using dynamic panel estimation techniques, they find that economic growth and lower interest rates decreases NPLs. Moreover, an increase in bank size, bank expenses and lagged credit growth deteriorate the asset quality of banks. In another study, Boudriga et al. (2009) explores a panel of 59 countries for the period 2002-2006 by using fixed effects panel data estimation techniques. Their results suggest that higher capital adequacy ratios and higher provisions led to a decrease in the level of problem loans. Moreover, private ownership, foreign participation, and bank concentration increases the asset quality of banks. Nkusu (2011) uses a panel of 26 advanced economies from 1998 to 2009 and employs singleequation panel regressions using both OLS and GMM estimators. The results show that slower economic growth, higher unemployment rate and falling asset prices lead to a rise in 
NPL ratios. Beck et al. (2013) work on a dataset of 75 countries from 2000 to 2010 and study the macroeconomic determinants of NPLs using both static and dynamic panel data estimation techniques. The significant indicators of NPLs include real GDP growth rate, exchange rate, share prices and lending interest rate. Castro (2013) focuses on GIPSI (Greece, Ireland, Portugal, Spain and Italy) countries for the years 1997-2011 and uses dynamic panel data estimation techniques. They observe that a decrease in GDP growth and housing prices increases bank credit risk. On the other hand, a rise in unemployment rate, interest rate and credit growth increases bank credit risk. While appreciation of the real exchange rate decreases bank credit risk, the recent financial crisis significantly increased credit risk of banks. Jakubik and Reininger (2013) investigate the indicators of credit risk in Central, Eastern and Southeastern Europe for the years 2004 to 2012. Their results, employing GMM estimation techniques, indicate that an increase in economic growth and stock index decreases NPLs. On the other hand, lagged credit growth and the nominal exchange rate increase the level of NPLs. Skarica (2014) uses a sample of 7 Central and Eastern European countries for the years 2007-2012 and use panel data estimation techniques with ordinary least squares estimators and including fixed effects. Their findings indicate that the primary driver of NPLs is economic growth. Moreover they find that both higher unemployment and inflation rates raises the level of NPLs. Makri et al. (2014) uses a sample of 14 countries in the Eurozone for the period 2000-2008 and employ the difference Generalized Method of Moments (GMM) estimation techniques. They show that the significant macroeconomic indicators of NPLs include unemployment, public debt, and the GDP growth rate. Bank-level indicators of NPLs are listed as the capital adequacy ratio and return on equity. Klein (2013) explore the bank level and macroeconomic indicators of NPLs using a sample of CESEE economies over the years 1998-2011. Their methodology includes fixed effects and system GMM techniques. Their results show that higher unemployment, exchange rate depreciation, higher inflation and higher global risk aversion decreases asset quality of banks. On the other hand, higher GDP growth increases the asset quality of banks. Among the bank-level indicators, the results show that the increase in equity-to-asset ratio and return on equity (ROE) decreases NPLs. On the other hand, an increase in lending as measured by the loan-to-asset ratio and the past growth rate of lending, leads to higher NPLs.

The most of the empirical literature focuses on single countries. When we consider the highly cited and most important single-country studies, Salas and Saurina's work in 2002 draws the first attention. They use a sample of Spanish banks for the period 1985-1997 and investigate macroeconomic and microeconomic indicators of NPLs. They find that bank size, net interest margin, market power, real GDP growth, inefficiency, capital ratio, the growth of past credit and composition of the portfolio are significant determinants of bank credit risk. Higher capital ratio decreases NPLs and increased bank size decreases NPLs. Louzis et al. (2010) is another seminal study that focuses on Greek banks and use dynamic panel data estimation techniques to examine the determinants of loan quality. They use a sample of 9 largest Greek banks for the period 2003-2009 and consider the determinants of different types of loan's quality such as mortgages, business loans, and consumer loans. They find that GDP, unemployment, interest rates and management quality are the important determinants of the credit risk of Greek banks. The credit risk decreases when there is a 
surge in economic growth. Bank specific variables that significantly explain NPLs include performance indicators (ROA and ROE) and inefficiency index (as proxied by the ratio of operating expenses to operating income). While an increase in performance indicators decreases NPLs, an increase in inefficiency index increases the level of NPLs. Ghosh (2015) employs a sample of 50 states in the US for the period 1884-2013 and uses both fixed effects and GMM estimators. The author observes that larger bank size, cost inefficiency, poor quality of credit, higher capitalization and liquidity risks increase credit risk of banks. On the other hand, more profitable banks have lower NPLs. Concerning macroeconomics indicators, it is found that real GDP and real personal income growth of the states and increases in housing prices decrease credit risk of banks. Conversely, the macroeconomic determinants that increase credit risk of banks include inflation, state unemployment rates, and US public debt.

There is a limited number of studies focusing on Turkey. One of them is Macit (2012) which explores the bank-specific and macroeconomic determinants of NPLs by employing quarterly data for 15 largest commercial Turkish banks for the years 2005- 2010. They use pooled feasible generalized least squares and dynamic panel data estimation techniques. They show that while banks with a higher equity to total asset ratio and a higher net interest margin have higher NPLs ratios, banks with higher loans to asset ratio have significantly lower NPLs. Moreover, public banks and foreign banks have higher NPLs ratios and domestic currency depreciation deteriorates the loan portfolios. A decrease in GDP growth leads to increased NPLs with a lag, specifically after two quarters. Another study on Turkey is Isik and Bolat (2016) that use a sample of 20 Turkish deposit banks and investigate the determinants of NPLs ratio for the period 2006-2012. They employ panel data estimation techniques and control for endogeneity by using lagged independent variables. Their results indicate that an increase in capitalization (as proxied by equity to total asset ratio) and loan loss provisions (proxied by loan loss provisions to total assets) led to an increase in the NPLs. On the other hand, profitability (as proxied by ROA), income diversification (non-interest income to total assets) and economic growth (annual real GDP growth rate) significantly decrease NPLs. Us (2016) is another study focusing on Turkey and explores the bank-level and macroeconomic indicators of NPLs in Turkish banks for the period 2002-2015. Their methodology includes both using panel estimation techniques via fixed effects and system GMM to account for endogeneity. They find that an increase in lending (as proxied by loans to asset ratio), inefficiency (measured by other operating expenses/total assets) and size of banks led to an increase in NPLs. While higher GDP growth significantly decreases NPLs, an increase in inflation and the depreciation of Turkish lira triggers NPLs. The analysis further shows that the global 2007-2009 financial crisis has a major impact on the determinants of NPLs.

\section{Data and Methodology}

\subsection{Methodology}

As a starting point, we initially perform our analysis using traditional panel data estimation techniques by using Ordinary Least Squares (OLS) estimators with pooled-OLS 
and fixed effects. Fixed effects control for unobserved heterogeneity across banks. The estimated model is provided in Equation 3.1 below:

$$
N P L_{i t}=\alpha N P L_{i t-1}+\beta * X_{i t}+\mu_{i}+\varepsilon_{i t}
$$

where bank and time are denoted by the subscripts $\mathrm{i}$ and t respectively. $\beta$ is a $1 \mathrm{x}$ k vector of coefficients and $X_{i t}$ is a $1 \mathrm{x} \mathrm{k}$ vector of explanatory variables. Explanatory variables include both bank-level and macroeconomic determinants of NPLs. While $\mu_{i t}$ stands for unobserved bank-specific effects, $\varepsilon_{i t}$ corresponds to error terms.

Due to the persistence of NPL ratio and endogeneity concerns due to reverse causality, we include lagged NPL ratio as an independent variable in the model. However, this leads to the problem of autocorrelation and the least square estimators become biased and inconsistent. Specifically, the lagged NPL ratio becomes correlated with the fixed effects term in error. To eliminate this problem and following the literature (Espinoza \& Prasad, 2010; Klein, 2013; Jakubik \& Reininger, 2013), dynamic panel estimation techniques are employed which take into account the persistence of NPL ratio. The difference GMM methodology proposed by Arellano and Bond (1991) transforms the model into first differences to remove the fixed effects and correlations. However, the estimation has a low amount of precision with samples including a short time dimension $(\mathrm{T})$ and a high level of persistence (Blundell \& Bond, 1998). To take into account this concern, we use a system GMM estimation developed Arellano and Bover (1995) and Blundell and Bond (1998) with standard errors robust to heteroskedasticity. Two simultaneous equations are estimated in system GMM estimation which are the equation in levels (lagged first differences are considered as instruments) and the one in differences (lagged levels are taken as instruments).

The instruments in the Arellano Bond estimation are the available lags of the dependent variables and the lagged values of the regressors (Roodman, 2009a). While the variables considered as endogenous or predetermined are instrumented with GMM-style instruments, the variables that are strictly exogenous are instrumented by standard instrumental variables, namely instrumented by themselves. In our analysis, we consider the lagged dependent variable and the bank-specific controls as predetermined and instrument them GMM-style. Following the extant literature, macroeconomic variables, such as real GDP per capita growth and inflation, are considered to be strictly exogenous and instrumented by themselves (Roodman, 2009b; Espinoza \& Prasad, 2010; Klein, 2013; Jakubik \& Reininger, 2013). The limited number of banks in our analysis restricts the number of instruments that can be employed in the estimation. Misleading asymptotic inferences may be obtained when the number of instruments is greater than the number of banks because standard errors and Hansen test would be biased downwards (Louzis et al., 2010). Since the rule of thumb is to keep the number of instruments lower than the number of groups (Roodman, 2009a), we, therefore, carefully choose the number of instruments to be lower than the number of banks. We reduce the number of instruments by implementing the collapsing method as proposed in Holtz-Eakin, Newey, and Rosen (1988). We further conduct the forward orthogonalization procedure of Arellano and Bover (1995) to limit the 
observation losses that occur due to differencing. Arellano and Bond (1991) introduce twostep GMM estimator with a consistent variance-covariance matrix of the moment conditions that relaxes homoscedasticity assumptions and brings efficiency gains. However, efficiency gains are found not to be that important (Blundell \& Bond, 1998; Blundell et al., 2000) and the one-step estimator is found to outperform the two-step estimator (Judson \& Owen, 1999). Moreover, two-step estimators bring a downward bias in standard errors that lead to the problem of unreliable statistical inferences, especially in small cross-section dimension (Bond \& Windmeijeir, 2002; Windmeijer, 2005). Therefore, we choose to employ one-step estimator.

The validity of the instruments is very crucial for a reliable GMM estimation. Therefore, we perform some specification tests to validate our GMM estimation. The specification tests the Arellano-Bond system GMM estimation include Arellano-Bond $\mathrm{AR}(1)$ and $\mathrm{AR}(2)$ tests for the first and second order autocorrelation of the residuals and the Hansen test of overidentifying restrictions. Since the null hypothesis for AR(1) and AR(2) tests is no serial correlation of the residuals, we should reject the null hypothesis for AR(1) test and not reject for $\mathrm{AR}(2)$ test. Rejecting the null hypothesis for $\mathrm{AR}(1)$ test is expected since differencing automatically generates an autocorrelation of order 1 . The null hypothesis for the Hansen test is that the instruments used in all the specifications are appropriate and we expect to not reject the null hypothesis.

\subsection{Data}

The primary source of bank level data is Fitch Connect Database from Fitch Solutions. Annual data on 27 private and listed Turkish banks are considered for the years 2007-2015. All value data are expressed in US dollars. Although most of the variables are in ratios, the ones that are in levels are expressed in 2010 US dollars to remove the effect of inflation. Data for macroeconomic variables are obtained from the World Bank World Development Indicators database. The variables used in the analysis are provided in a summary table in Table 1 and details on the variables are provided below.

\subsubsection{Dependent Variable}

The definition of NPL ratio employed in the analysis is the ratio of non-performing loans to gross loans. Following the literature, the natural logarithm transformation is used because NPL ratio is highly skewed. Table 2 shows the descriptive statistics of the variables that are used in the analysis. It is seen that NPL ratio ranges from $0.17 \%$ to $17.28 \%$, with an average of $3.48 \%$ and a standard deviation of $2.07 \%$. Moreover, Figure 1 depicts that the average NPLs ratio of our sample of 27 banks shows an increasing pattern from $2.95 \%$ in 2007 to $5.27 \%$ in 2009 which coincides with the period of the sub-prime mortgage crisis of 2007-2009. But then NPLs ratio starts gradually decreasing and the asset quality of banks improved, specifically NPLs ratio down to $3.01 \%$ in 2013 and $3.03 \%$ in 2015. 


\subsubsection{Independent Variables}

Our independent variables and determinants of credit risk are chosen from the extant literature which are the commonly used bank-level and macroeconomic determinants of bank credit risk. As indicated in the literature review section, there are two sets of factors that explain NPLs ratio of banks. The first group considers the variability across banks and emphasizes the importance of bank-specific factors to explain the NPLs. The second group focuses on macroeconomic conditions which likely impact borrower's conditions to repay their debts. Since empirical evidence find support for both of these factors, we focus on both.

- Bank size: While bank size is considered to be an important determinant of bank credit risk in the literature, the impact of bank size on NPLs is rather ambiguous. Bank size decreases NPLs because larger banks have more opportunities to diversify their risks and screen their loans in a better way (Salas \& Saurina, 2002; Hu et al., 2004). On the other hand, too-big-to-fail banks expect to be rescued by the government in the case of any failure and they, therefore, assume greater credit risks (Stern \& Feldman, 2004). We calculate bank size as the natural logarithm of total assets and since it is highly skewed, the variable is taken in natural logarithm. Table 2 shows that total assets of banks in our sample range from 0.10 billion USD to 109.95 billion USD, with an average value of 28.29 billion USD.

- Equity to Total Assets: Capital adequacy ratio is another important determinant of bank risk in the literature with mixed findings on bank credit risk. Banks with a low amount of capital are found to have higher risk exposures and face higher credit risks (Berger \& DeYoung, 1997; Salas \& Saurina, 2002). On the other hand, banks with a high level of capital may have increased credit risk because they may have an incentive to increase their capital to act as a buffer for their credit risks which encourage them to behave in a riskier way (Koehn \& Santomero, 1980; Rime, 2001). We calculate capital adequacy ratio as the ratio of equity to total assets. Table 2 shows that equity to total assets of banks in our sample ranges from $5.52 \%$ to $63.22 \%$, with an average value of $12.39 \%$.

- ROA: ROA is a proxy for bank performance and has again an ambiguous influence on bank credit risk. Higher profitability increases NPLs because higher profits provide an incentive for risky behavior (García-Marco \& RoblesFernández, 2008). Moreover, a bank may inflate its current earnings by adopting liberal credit policies and hide the extent of problematic loans, aiming to convince the market of its credit evaluation abilities (Rajan, 1994). On the other hand, lower profitability proxy for bad management skills which in turn lead to riskier activities and an increase in NPLs, consistent with bad management hypothesis (Berger \& DeYoung, 1997; Louzis et al., 2010). We calculate ROA as net income to total assets. Table 2 displays that ROA in our sample ranges from $-6.21 \%$ to $3.48 \%$, with an average of $1.43 \%$. 
- Loans to assets: The loan to asset ratio is a lending and liquidity ratio and indicates the proportion of assets tied up in loans. An increase in the lending ratio may indicate excessive growth in loans and increase the credit risk of banks (Keeton \& Morris, 1987; Salas \& Saurina, 2002).

On the other hand, an increase in lending may bring more stringent lending criteria and decrease credit risk of banks (Khemraj \& Pasha, 2009; Vithessonthi, 2016). We calculate loans to asset ratio as total loans to total assets. Table 2 displays that loans to asset ratio in our sample ranges from $17.53 \%$ to $83.83 \%$, with an average of $61.95 \%$.

- Noninterest income share: is a percentage of non-interest income in total income and proxies for the composition and diversification of bank revenues. Where noninterest income includes net income from fees, asset trading and securities and insurance activities; total income consists of both interest and non-interest income. Banks with diversified activities that generate non-interest income are expected to decrease their credit risks. Moreover, different revenue sources by diversification enable banks to refrain from risky borrowers (Hu et al., 2007; Louzis et al., 2010). In our sample, noninterest income share ranges from $-50.60 \%$ to $50.34 \%$, with a mean of $24.34 \%$.

- Loan Loss Provisions share: computed as loan loss provisions to total interest income with higher values indicating that risk is not properly counterbalanced by higher margins and reflects higher credit risk. Loan loss provisions are regarded as an allowance for loan defaults. Therefore, higher levels of loan loss provisions are expected to lead to higher levels of NPLs (Hasan \& Wall, 2004; Boudriga et al., 2009).

- Revenue growth: It is proxied by the growth of total operating income which is another performance indicator and controls the bank's business strategy and asset development. It ranges from $-19 \%$ to $84 \%$ with an average of $6 \%$.

- Fixed to total assets ratio: Asset composition and tangibility is captured by this ratio. Higher values indicate lower tangibility and expected to decrease bank franchise value and increase bank risk (Gonzalez, 2005). It is computed as the ratio of fixed assets to total assets. Table 2 displays that fixed to total assets ratio ranges from $0.16 \%$ to $4.78 \%$ with an average value of $1.20 \%$.

- Other operating expenses to total assets: is a proxy for inefficiency with an increase in this ratio indicating a rise in inefficiency. Higher inefficiency and bad management indicate poor screening and quality of loans and an increase in the credit risk of banks (Berger \& DeYoung, 1997; Williams, 2004). Moreover, high efficiency implies a decrease in the quality of monitoring lending risks that may further lead to higher NPLs (Berger \& DeYoung, 1997). In our sample, other operating expenses to total assets range from $0.28 \%$ to $5.81 \%$ with an average of $1.79 \%$. 
- Real GDP per capita growth: The growth in real GDP per capita improves the economic conditions and debt servicing capacity of borrowers and generally found to lead to lower bank credit risk (Salas \& Saurina, 2002; Nkusu, 2011). Real GDP per capita is measured as annual percentage growth rate of GDP per capita. Table 2 shows that real GDP capita growth in Turkey between the years 2007 and 2015 ranges from $-6.05 \%$ to $7.57 \%$ with an average value of $1.98 \%$.

- Inflation: The impact of inflation on bank credit risk is also ambiguous and its influence on NPLs can be either positive or negative. On the one hand, higher inflation reduces the real value of loans and decreases bank credit risk. On the other hand, if wages are sticky, borrower's real income is diminished which leads to problems in repaying their loans (Nkusu, 2011). Inflation is calculated as the annual growth rate of the GDP implicit deflator. Turkish inflation between the years 2007 and 2015 ranges from $6.25 \%$ to $10.44 \%$, with an average of $8.16 \%$.

\section{Table: 1}

\section{Definition of the Variables}

\begin{tabular}{ll}
\hline Name of variables & Description \\
\hline $\begin{array}{l}\text { Panel A: Dependent variable } \\
\text { Nonperforming Loans ratio }\end{array}$ & Nonperforming loans to gross loans \\
$\begin{array}{l}\text { Panel B: Bank Controls } \\
\text { Bank size }\end{array}$ & The natural logarithm of total assets \\
Equity to total assets & Shareholders equity to total assets \\
ROA & Net income to total assets \\
Loans to assets & The ratio of loans to total assets \\
Noninterest income share & Noninterest income to total income \\
Loan loss provisions share & Loan loss provisions to net interest revenue \\
Revenue growth & The growth of total operating income \\
Fixed to total assets & The ratio of fixed assets to total assets \\
Other oper. exp. to total assets & The ratio of other operating expenses to total assets \\
Panel C: Macroeconomic variables & \\
Real GDP per capita growth & Annual percentage growth rate of GDP per capita \\
Inflation & The annual growth rate of the GDP implicit deflator \\
\hline Note: $:$ This table shows the list of variables and brief descriptions of them. While Panel A lists the dependent \\
variable; Panel B and C specifies the bank controls and macroeconomic variables, respectively.
\end{tabular}

Table: 2

Descriptive Statistics

\begin{tabular}{|c|c|c|c|c|c|c|}
\hline Variable & $\mathrm{N}$ & mean & $\min$ & $\max$ & p50 & $\mathrm{sd}$ \\
\hline NPL ratio & 213 & $3.48 \%$ & $0.17 \%$ & $17.28 \%$ & $3.07 \%$ & $2.07 \%$ \\
\hline Total assets (billion USD) & 219 & 28.29 & 0.10 & 109.95 & 11.50 & 32.58 \\
\hline Equity to total assets & 219 & $12.39 \%$ & $5.52 \%$ & $63.22 \%$ & $11.37 \%$ & $5.81 \%$ \\
\hline ROA & 219 & $1.43 \%$ & $-6.21 \%$ & $3.48 \%$ & $1.47 \%$ & $0.95 \%$ \\
\hline Loans to assets & 219 & $61.95 \%$ & $17.53 \%$ & $83.83 \%$ & $64.44 \%$ & $12.79 \%$ \\
\hline Other oper. exp. to TA & 219 & $1.79 \%$ & $0.28 \%$ & $5.81 \%$ & $1.54 \%$ & $0.88 \%$ \\
\hline Noninterest income share & 219 & $24.34 \%$ & $-50.60 \%$ & $50.34 \%$ & $26.51 \%$ & $12.06 \%$ \\
\hline LoanLossProv. Share & 218 & $16.49 \%$ & $-15.20 \%$ & $146.12 \%$ & $14.54 \%$ & $13.63 \%$ \\
\hline Revenue growth & 192 & $5.21 \%$ & $-34.28 \%$ & $120.66 \%$ & $-2.62 \%$ & $25.32 \%$ \\
\hline Fixed to total assets & 219 & $1.20 \%$ & $0.16 \%$ & $4.78 \%$ & $0.99 \%$ & $0.79 \%$ \\
\hline Real GDP percapgrowth & 243 & $1.98 \%$ & $-6.05 \%$ & $7.57 \%$ & $2.31 \%$ & $3.85 \%$ \\
\hline Inflation & 243 & $8.16 \%$ & $6.25 \%$ & $10.44 \%$ & $8.57 \%$ & $1.25 \%$ \\
\hline
\end{tabular}

Note: The table shows summary statistics for the bank and country controls.

Table A in the Appendix displays correlation coefficients among the independent variables which show no indication of multicollinearity problem. 


\section{Figure: 1}

\section{The Average NPLs Ratio of the Sample of 27 Turkish Banks Over 2007-2015}

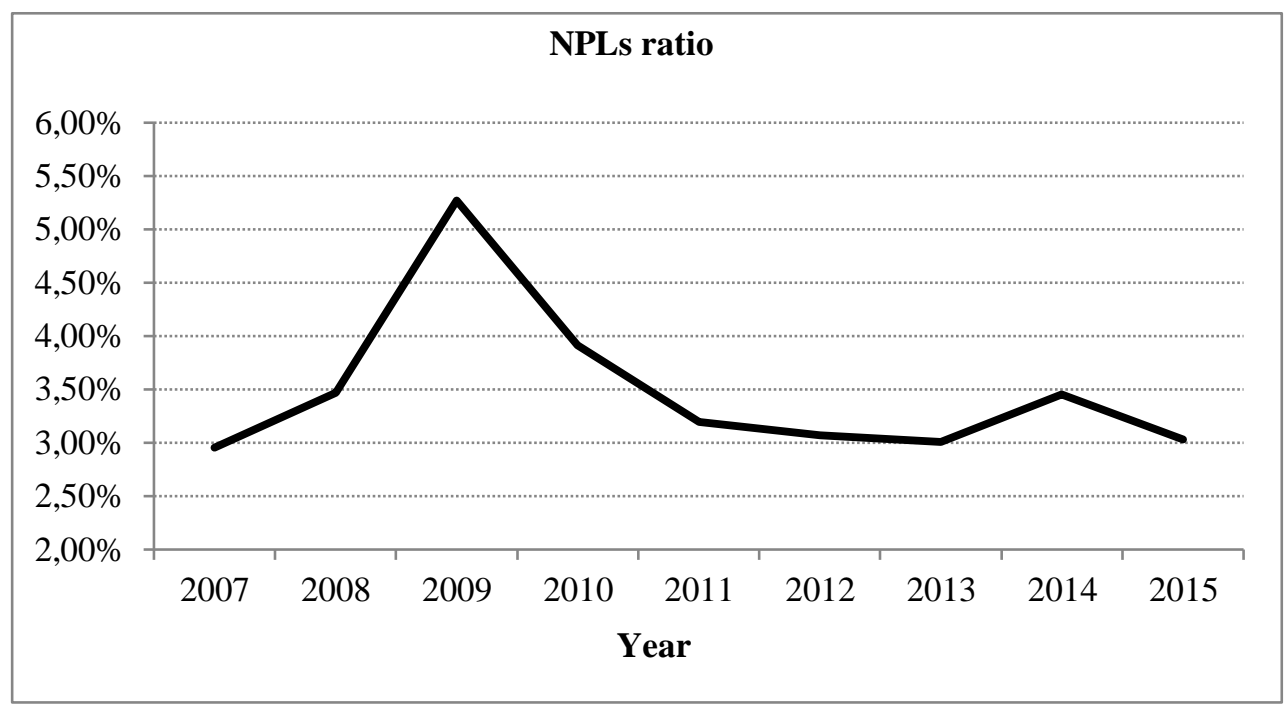

\section{Results}

Table 3 displays our results where we use bank-level clustered robust standard errors to account for heteroskedasticity and autocorrelation, time dummies to account for heterogeneity between the years and standard errors are provided in parentheses. While Column 1 is estimated using pooled- OLS estimators, Column 2 is estimated using fixed effects. The Lagged NPL ratio is statistically significant and positive under all estimations which reveals that past values of NPL ratio affect current NPL ratio and reveals the persistence of NPL ratio in the Turkish context, confirming that the dynamic specification is relevant.

While the coefficient on lagged NPL ratio under pooled OLS is 0.701 ; the coefficient falls to 0.423 under fixed effects both of which are estimated using OLS estimators. As indicated in Section 3, having lagged NPL ratio as an independent variable in the model leads to the problem of autocorrelation and the least square estimators become biased and inconsistent. The reason is that the lagged NPL ratio becomes correlated with the error term. The coefficient estimate of lagged dependent variable becomes biased upward under the pooled-OLS estimation and biased downward under the fixed effects estimation. Therefore, to remedy this problem, a dynamic panel estimation technique is employed in Column 3 which takes into account the persistence of NPL ratio. As indicated by Bond (2002) and Roodman (2009a), good estimates of the true parameter of lagged NPL ratio should lie in the range of 0.423 and 0.701 which provides us a range on the coefficient estimate of lagged NPL ratio to check our results of the system GMM estimation. 
We perform some diagnostic tests for system GMM estimation. The first one is the Hansen test to check for the potential misspecification of models which is displayed at the bottom of Table 3. The Hansen $\mathrm{J}$ statistic has a p-value of 0.322 which leads us to not reject the null hypothesis, namely the instruments used in all the specifications are appropriate and confirms the validity of system GMM dynamic model. Moreover, Arellano-Bond AR(1) and $\mathrm{AR}(2)$ tests are employed for the first and second order autocorrelation of the residuals. Since the null hypothesis for AR(1) and AR(2) tests is no serial correlation of the residuals, we should reject the null hypothesis for $\operatorname{AR}(1)$ test and not reject for $\operatorname{AR}(2)$ test. Table 3 shows that $\mathrm{p}$-values for $\mathrm{AR}(1)$ and $\mathrm{AR}(2)$ tests are 0.011 and 0.52 , respectively which confirms a valid specification.

Table: 3

Estimation Results for Credit Risk Determinants

\begin{tabular}{|c|c|c|c|}
\hline & (1) Pooled OLS & (2) FE & (3) GMM \\
\hline \multirow{2}{*}{ L.NPL } & $0.701 * * *$ & $0.423 * * *$ & $0.667 * *$ \\
\hline & $(0.039)$ & $(0.063)$ & $(0.286)$ \\
\hline \multirow[t]{2}{*}{ Size } & $-0.035^{* * *}$ & -0.055 & 0.056 \\
\hline & $(0.016)$ & $(0.148)$ & $(0.119)$ \\
\hline \multirow[t]{2}{*}{ Equity to total assets } & $-0.976^{* * *}$ & $-1.582^{* *}$ & -0.804 \\
\hline & $\begin{array}{l}(0.492) \\
9.218^{* * *}\end{array}$ & $\begin{array}{c}(0.775) \\
14.514 * * *\end{array}$ & $\begin{array}{c}(1.350) \\
26.918^{* *}\end{array}$ \\
\hline ROA & (3.614) & $(4.773)$ & $(12.177)$ \\
\hline \multirow[t]{2}{*}{ Loans to assets } & -0.099 & $-1.147 * * *$ & $-2.087^{*}$ \\
\hline & $(0.196)$ & $(0.334)$ & (1.148) \\
\hline \multirow[t]{2}{*}{ Other oper. exp. to total assets } & $7.448 * *$ & $14.008^{* *}$ & $24.609 * *$ \\
\hline & $(2.995)$ & $(5.799)$ & $(10.078)$ \\
\hline \multirow[t]{2}{*}{ Noninterest income share } & $-0.683^{* * *}$ & $-0.537 *$ & $-2.023^{*}$ \\
\hline & $(0.217)$ & $(0.323)$ & (1.004) \\
\hline \multirow{2}{*}{ LoanLossProv. Share } & $1.337 * * *$ & $1.294 * * *$ & $2.030 * * *$ \\
\hline & $(0.196)$ & $(0.238)$ & $(0.605)$ \\
\hline \multirow[t]{2}{*}{ Revenue growth } & $-0.215^{*}$ & $-0.397 * * *$ & -0.369 \\
\hline & $(0.126)$ & $(0.147)$ & $(0.281)$ \\
\hline \multirow[t]{2}{*}{ Fixed to total assets } & $7.028 * * *$ & $13.333 * * *$ & 9.152 \\
\hline & $(2.648)$ & $(4.006)$ & (10.409) \\
\hline \multirow[t]{2}{*}{ Real GDP percapgrowth } & 0.199 & 1.251 & -0.005 \\
\hline & $(0.594)$ & $(0.760)$ & $(0.019)$ \\
\hline \multirow[t]{2}{*}{ Inflation } & 0.264 & $1.318^{*}$ & -0.156 \\
\hline & $(0.639)$ & $(0.793)$ & $(0.324)$ \\
\hline \multirow{2}{*}{ Constant } & -3.482 & $-14.453 * *$ & \\
\hline & $(6.374)$ & $(7.121)$ & \\
\hline R-sqr & 0.853 & 0.653 & \\
\hline Observations & 184 & 184 & 184 \\
\hline Number of groups (banks) & 27 & 27 & 27 \\
\hline Number of instruments & & & 26 \\
\hline AR1 p-value & & & $0.011 * * *$ \\
\hline AR2 p-value & & & 0.56 \\
\hline Hansen $\mathbf{J}$ statistic & & & 8.12 \\
\hline Hansen p-value & & & 0.322 \\
\hline
\end{tabular}

Note: The table provides information on the determinants of credit risk using a sample of 27 Turkish banks for the period 2007-2015. Robust standard errors in parentheses.

$* p<0.10, * * p<0.05, * * * p<0.010$.

The results from Column 3 indicates that most of the explanatory variables show statistically significant coefficients and are able to explain the NPLs ratio of Turkish banks. These variables include ROA, Loans to assets, other operating expenses to total assets, noninterest income share and loan loss provisions to net interest revenue. It is found that more profitable banks with a higher ROA have higher NPLs ratios, which is in line with the findings of Rajan (1994) and García-Marco \& Robles-Fernández (2008). Higher profitability provides an incentive for risky behavior and increases NPL ratios of Turkish banks. 
Moreover, banks may inflate their current earnings and hide the extent of problematic loans by employing liberal credit policies to show the market their credit evaluation abilities. Our results further indicate that banks with higher loans to asset ratio have lower NPLs ratio, consistent with Khemraj and Pasha (2009), Macit (2012) and Vithessonthi (2016). Therefore, an increase in lending may bring more stringent lending criteria and decrease NPLs of Turkish banks. Moreover, inefficient banks with higher other operating expenses to total assets are found to have higher credit risk which is in line with Berger \& DeYoung (1997), Williams (2004), Louzis et al., (2010), Espinoza \& Prasad (2010), Ghosh (2015) and Us (2016). Therefore, inefficiency as a proxy for bad management leads to poor screening and poor quality of loans and increases Turkish banks' NPLs. It is further observed that banks with higher noninterest income share have lower credit risk, a result consistent with $\mathrm{Hu}$ et al., (2007), Louzis et al., (2010) and Isik \& Bolat (2016). Hence, diversified activities and different revenue sources enable banks to refrain from risky borrowers and decrease the amount of NPLs. Finally, it is observed that banks with higher loan loss provisions to net interest revenue have a higher NPLs ratio, which is consistent with Hasan \& Wall (2004), Boudriga et al. (2009) and Isik \& Bolat (2016). Therefore, the higher amount of loan loss provisions indicate that risk is not properly counterbalanced by higher margins and therefore banks face increased credit risks.

\section{Conclusion}

In this paper, we conduct a financial statement analysis of Turkish banks and examine the indicators of NPLs. We use annual data on 27 private and listed Turkish banks for the years 2007-2015 and employ dynamic panel data estimation techniques by using the system GMM estimation techniques developed by Arellano and Bover (1995) and Blundell and Bond (1998). Our results are in line with our hypothesis which states that bank-specific factors are the most important indicators of credit risk of Turkish banks. Specifically, it is found that more profitable and inefficient banks, and banks with higher loan loss provisions share have higher NPLs. On the other hand, banks with higher loans to asset ratio and a higher noninterest income share have lower credit risk.

These findings offer some important policy implications for regulatory authorities. An increase in profitability, inefficiency and loan loss provisions share increases banks' incentives to increase their credit risks, therefore, they need to be monitored closely. In addition, a higher loan share in total assets and a higher noninterest income share tends to reduce the risky behavior of banks and increase their stability. Future research could explore the different bank-specific determinants of bank credit risk and explore the impact of interactions between different bank characteristics on bank credit risk. The influence of different macroeconomic and regulatory variables on nonperforming loans of banks could be explored. These macroeconomic and regulatory variables could include measures such as the exchange rate, the different corporate governance measures, bank private sector credit to GDP ratio and capital requirements. 


\section{References}

Arellano, M. \& S. Bond (1991), "Some Tests of Specification for Panel Data: Monte Carlo Evidence and an Application to Employment Equations", The Review of Economic Studies, 58(2), 277-297.

Arellano, M. \& O. Bover (1995), "Another look at the instrumental variable estimation of errorcomponents models", Journal of Econometrics, 68(1), 29-51.

Beck, R. \& P. Jakubik \& A. Piloiu (2013), "Non-performing loans: what matters in addition to the economic cycle?", Working Paper Series No. 1515, European Central Bank.

Berger, A.N. \& R. DeYoung (1997), "Problem loans and cost efficiency in commercial banks", Journal of Banking \& Finance, 21(6), 849-870.

Bernanke, B. \& M. Gertler (1989), “Agency Costs, Net Worth, and Business Fluctuations”, The American Economic Review, 79(1), 14-31.

Blundell, R. \& S. Bond (1998), "Initial conditions and moment restrictions in dynamic panel data models", Journal of Econometrics, 87(1), 115-143.

Blundell, R. \& S. Bond \& F. Windmeijer (2000), "Estimation in dynamic panel data models: improving on the performance of the standard GMM estimator", IFS Working Paper, W00/12, Institute for Fiscal Studies.

Bond, S. (2002), "Dynamic panel data models: a guide to microdata methods and practice", CeMMAP working paper, No. CWP09/02, Centre for Microdata Methods and Practice, Institute for Fiscal Studies.

Bond, S. \& F. Windmeijer (2002), "Finite sample inference for GMM estimators in linear panel data models", CeMMAP working papers, CWP04/02, Centre for Microdata Methods and Practice, Institute for Fiscal Studies, London, UK.

Boudriga, A. \& N.B. Taktak \& S. Jellouli (2009), "Banking supervision and nonperforming loans: a cross-country analysis", Journal of Financial Economic Policy, 1(4), 286-318.

Castro, V. (2013), "Macroeconomic determinants of the credit risk in the banking system: The case of the GIPSI", Economic Modelling, 31, 672-683.

Central Bank of the Republic of Turkey (2013), "Financial Stability", Press Release, May, Ankara, <http://www.tcmb.gov.tr>, 25.12.2017.

Central Bank of the Republic of Turkey (2017), "Financial Stability", Press Release, November. Ankara, <http://www.tcmb.gov.tr>, 25.12.2017.

Espinoza, R. \& A. Prasad (2010), "Nonperforming Loans in the GCC Banking System and their Macroeconomic Effects", IMF Working Paper, 10/224. International Monetary Fund.

García-Marco, T. \& M.D. Robles-Fernández (2008), "Risk-taking behavior and ownership in the banking industry: The Spanish evidence", Journal of Economics and Business, 60(4), 332-354.

Ghosh, A. (2015), "Banking-industry specific and regional economic determinants of nonperforming loans: Evidence from US states", Journal of Financial Stability, 20, 93-104.

Gonzalez, F. (2005), "Bank regulation and risk-taking incentives: An international comparison of bank risk", Journal of Banking \& Finance, 29(5), 1153-1184.

Hansen, L.P. (1982), "Large Sample Properties of Generalized Method of Moments Estimators", Econometrica, 50(4), 1029-1054. 
Hasan, I. \& L.D. Wall (2004), "Determinants of the Loan Loss Allowance: Some Cross-Country Comparisons", Financial Review, 39(1), 129-152.

Holtz-Eakin, D. \& W. Newey \& H.S. Rosen (1988), "Estimating Vector Autoregressions with Panel Data", Econometrica, 56(6), 1371-1395.

Hu Jin-Li, Li Yang \& Chiu Yung-Ho (2007), “Ownership and nonperforming loans: evidence from taiwan's banks", The Developing Economies, 42(3), 405-420.

Isik, O. \& S. Bolat (2016), "Determinants of nonperforming loans of deposit banks in Turkey", Journal of Business, Economics and Finance, 5(4), 341-350.

Jakubík, P. \& T. Reininger (2013), "Determinants of Nonperforming Loans in Central, Eastern and Southeastern Europe", Focus on European Economic Integration, (3), 48-66.

Judson, R.A. \& A. Owen (1999), "Estimating dynamic panel data models: a guide for macroeconomists", Economics Letters, 65(1), 9-15.

Keeton, W. \& C. Morris (1987), “Why Do Banks' Loan Losses Differ?”, Federal Reserve Bank of Kansas City Economic Review, May, 3-21.

Khemraj, T. \& S. Pasha (2009), "The determinants of non-performing loans: an econometric case study of Guyana", MPRA Paper, 53128, University Library of Munich, Germany.

Kiyotaki, N. \& J. Moore (1997), “Credit Cycles”, Journal of Political Economy, 105(2), 211-248.

Klein, N. (2013), "Non-Performing Loans in CESEE; Determinants and Impact on Macroeconomic Performance", IMF Working Papers, 13/72, International Monetary Fund.

Koehn, M. \& A. Santomero (1980), "Regulation of bank capital and portfolio risk", Journal of Finance, 35(5), 1235-1244.

Louzis, D.P. \& A.T. Vouldis \& V.L. Metaxas (2010), "Macroeconomic and Bank-Specific Determinants of Non-Performing Loans in Greece: A Comparative Study of Mortgage, Business and Consumer Loan Portfolios", SSRN Scholarly Paper, ID 1703026, Rochester, NY: Social Science Research Network.

Macit, F. (2012), "What Determines The Non-Performing Loans Ratio: Evidence From Turkish Commercial Banks", CEA Journal of Economics, 7(1), 33-39.

Makri, V. \& A. Tsaganos \& A. Bellas (2014), "Determinants of Non-Performing Loans: The Case of Eurozone”, SSRN Scholarly Paper, ID 2411932, Rochester, NY: Social Science Research Network.

Morakinyo, A.E. \& M. Sibanda (2016), “The Determinants of Non-Performing Loans in the 'MINT' Economies", Journal of Economics and Behavioral Studies, 8(5), 39-55.

Nkusu, M. (2011), "Nonperforming Loans and Macrofinancial Vulnerabilities in Advanced Economies", SSRN Scholarly Paper, ID 1888904, Rochester, NY: Social Science Research Network.

Ouhibi, S. \& S. Hammami (2015), "Determinants of nonperforming loans in the Southern Mediterranean countries", International Journal of Accounting and Economics Studies, 3(1), 50-53.

Rajan R. (1994), "Why Bank Credit Policies Fluctuate: A Theory and Some Evidence”, The Quarterly Journal of Economics, 109, 399-441.

Rime, B. (2001), "Capital requirements and bank behaviour: empirical evidence for Switzerland", Journal of Banking \& Finance, 25(5), 789-805.

Roodman, D. (2009a), "How to do xtabond2: An introduction to difference and system GMM in Stata”, Stata Journal, 9(1), 86-136. 
Roodman, D. (2009b), “A Note on the Theme of Too Many Instruments”, Oxford Bulletin of Economics and Statistics, 71(1), 135-158.

Salas, V. \& J. Saurina (2002), "Credit Risk in Two Institutional Regimes: Spanish Commercial and Savings Banks", Journal of Financial Services Research, 22(3), 203-224.

Skarica, B. (2014), "Determinants of non-performing loans in Central and Eastern European countries", Financial Theory and Practice, 38(1), 37-59.

Stern, G.H. \& R.J. Feldman (2004), Too Big To Fail: The Hazards of Bank Bailouts, Brookings Institution Press, Washington, DC, USA.

Us, V. (2016), "Determinants of Non-Performing Loans in the Turkish Banking Sector: What Has Changed After the Global Crisis?", The Central Bank of Turkey Research Notes in Economics, 16/27, 1-14.

Vithessonthi, C. (2016), "Deflation, bank credit growth, and non-performing loans: Evidence from Japan", International Review of Financial Analysis, 45, 295-305.

Williams, J. (2004), "Determining Management Behaviour in European Banking”, Journal of Banking \& Finance, 28(10), 2427-2460.

Windmeijer, F. (2005), “A Finite Sample Correction for the Variance of Linear Efficient Two-Step GMM Estimators", Journal of Econometrics, 126(1), 25-51. 


\section{Appendix: A}

Correlations

\begin{tabular}{|c|c|c|c|c|c|c|c|c|c|c|c|}
\hline & Size & $\begin{array}{c}\text { Equity to } \\
\text { TA }\end{array}$ & ROA & $\begin{array}{c}\begin{array}{c}\text { Loans to } \\
\text { assets }\end{array} \\
\end{array}$ & $\begin{array}{c}\text { Oper. exp. To } \\
\text { TA }\end{array}$ & $\begin{array}{c}\text { Nonint. Income } \\
\text { share }\end{array}$ & $\begin{array}{c}\text { LoanLossProv. } \\
\text { Share }\end{array}$ & Rev. growth & Fixed to TA & Real GDP pc growth & Inflation \\
\hline Size & 1 & & & & & & & & & & \\
\hline Equity to TA & $-0.4982 *$ & 1 & & & & & & & & & \\
\hline ROA & $0.2778^{*}$ & 0.1204 & 1 & & & & & & & & \\
\hline Loans to assets & 0.048 & $-0.1724 *$ & -0.0973 & 1 & & & & & & & \\
\hline Other oper. exp. to TA & $-0.2431^{*}$ & $0.2928^{*}$ & $-0.3819^{*}$ & -0.006 & 1 & & & & & & \\
\hline Nonint. income share & 0.0912 & 0.0126 & 0.1126 & $-0.2526 *$ & 0.113 & 1 & & & & & \\
\hline LoanLossProv. Share & 0.0499 & $-0.1360 *$ & $-0.5015^{*}$ & $0.1905^{*}$ & $0.2137 *$ & $0.1529 *$ & 1 & & & & \\
\hline Revenue growth & -0.1034 & $0.1901 *$ & $0.3084 *$ & -0.103 & -0.0926 & 0.0925 & 0.0328 & 1 & & & \\
\hline Fixed to total assets & -0.131 & $0.1902^{*}$ & 0.055 & -0.0133 & $0.3561 *$ & 0.016 & $-0.1554 *$ & 0.0575 & 1 & & \\
\hline Real GDP p.c. growth & 0.0417 & -0.0965 & -0.0601 & 0.0675 & -0.0709 & $0.1511 *$ & $-0.2692 *$ & $-0.4612^{*}$ & -0.1002 & 1 & \\
\hline Inflation & -0.0509 & 0.0784 & 0.0103 & -0.0263 & 0.0735 & -0.0834 & -0.0571 & -0.1061 & 0.0518 & 0.0497 & 1 \\
\hline
\end{tabular}

Note: This table shows correlation coefficients among independent variables.

* significance at 0.05 . 
Danışman, G.Ö. (2018), "Determinants of Bank Stability: A Financial Statement Analysis of Turkish Banks", Sosyoekonomi, Vol. 26(38), 87-103. 